\title{
The Limits of Rationalism: Early Modern Geography and the Idea of Europe
}

\author{
Adrian Christ
}

After the turn of the sixteenth century, European geographers were forced to reconsider their basic conception of the world's form as they realized the existence of vast new regions populated by diverse peoples in Africa, the Americans and Asia. This reconsideration sparked strong efforts by geographers to delimit Europe along geographic lines, efforts which can be traced through the physical representation of geographers' attitudes in cartography. Cartographers struggled to make maps appear more accurate and scientific while still retaining Europe's distinctiveness and doing homage to renowned classical texts. Investigating the efforts of cartographers in the sixteenth and seventeenth centuries informs understandings of not only the conceptual roots of modern geographic divisions, but also of early modern European identity and the growth of a scientific worldview.

Delimiting Europe, or the West, has long been a difficult task for geographers. Europe is a continent: it clearly has geographic limits, and has had them since it was first set apart from Asia by the classical Greeks. But those limits mark no real geographic difference, rather the furthest possible limits of a common sociocultural identity. A number of iterations of that sociocultural identity have appeared throughout history, but the one most adhered to today came to be during the radical changes of the early modern period. Vast new regions of the world needed to be mapped, as Europeans landed upon the Americas, Asia and sub-Saharan Africa and interacted with their populations. Cartographers took on the task of interpreting the geographic information pouring into Europe, and disseminating their interpretations across the continent. To do so, they at first used cosmographic systems of understanding before those gave way to ones more mathematical and measurement-based. Through this period, cartographers struggled to express Europe's sociocultural difference through geography. While some of Europe's geographic borders were and remain today quite arbitrary, cartographers and geographers began to use maps to demonstrate not only Europe's geographical distinctiveness, but also the features required for membership to its sociocultural bloc. Past iterations of Europe had been based upon the idea of a unified Christendom or the Greek sense of a civilized continent at odds with the barbarians of

\footnotetext{
${ }^{1}$ That Europe is a sociocultural entity is most clear along its Eastern border- the continent is obviously delineated by large bodies of water to its West, North and South; it is the Eastern boundary arbitrarily marked along mountains or watersheds that lacks a strong basis in geography.
} 
Asia, but the Europe that appeared over the course of the fifteenth to eighteenth centuries coalesced around secular ideas of European rationalism and intellect. Europe was where people pondered rather than lamented, debated rather than raged. Geographers and cartographers of the fifteenth to eighteenth centuries were one of the main impetuses behind the formation of the idea of a rational Europe, an idea which still holds strong today.

In order to demonstrate how the modern idea of Europe came to be, I will first summarize the origins of the concept of Europe and its development up until it reached its final early modern formation. Today's idea of Europe has important foundations in older geographic configurations of the continent. Then, I will survey the broader trends of geography, especially as pertaining to the growth of the map as a common means of representing the world. Maps gained significant prestige in this period as products of the convergence of the desire to scientifically represent nature, a belief in the truth of things deemed scientific, the need to understandably represent increasingly complicated European spheres of influence, and the pragmatic concerns of travel between distant commercial holdings. The final portion of the essay shows how the pre-existing idea of Europe, continually tied to its cartographic representation, shifted during the sixteenth to eighteenth centuries as a result of exoticism expressed through maps. Early modern cartography was an important means by which Europeans expressed, strengthened, and reconfigured the idea of Europe.

Efforts to define Europe have been encountering problems since they first began. While the inclusion of a region within Europe is never in doubt, its Eastern boundary is a hazy, ill-defined line tracing perhaps the Ural Mountains or perhaps the watersheds of important rivers flowing into the Black Sea. ${ }^{2}$ The arbitrary nature of its eastern geographic boundary does not negate the fact of Europe's conceptual existence, however, so since the Classical era geographers have wrestled with how to define the continent against the obvious evidence of the contiguous land connections between it and Asia. Herodotus commented in the fifth century BCE: "Another thing that puzzles me is why three distinct women's names [Libya/Africa, Europa, Asia] should have been given to what is in fact a single landmass." Evidently, confusion over the geographic division of these regions has existed for millennia, almost since the notion of Europe first appeared. While some have wrestled with the illogic of such a category, many others demonstrated "a continued awareness that these were constructed categories," rather than ones immediately apparent in the physical lay of the land. ${ }^{4}$ From its very beginning, Europe was far more a region built on sociocultural similarities than on any geographic distinctiveness.

\footnotetext{
${ }^{2}$ Martin W. Lewis and Kären E. Wigen, The Myth of Continents: A Critique of Metageography (Berkeley:

University of California Press, 1997), 27-8.

${ }^{3}$ Ibid., 22.

${ }^{4}$ Ibid., 23.
} 
The grounds for the sociocultural distinction between Europe and the rest of the world have shifted over the long history of the term. Edith Hall has traced Europe's beginnings to the Greek conception of themselves in opposition to "barbarians" in Asia. ${ }^{5}$ While some debate has occurred over the mechanism of the creation of the idea of Europe, the ancient Greek origins of the concept are rarely questioned by scholars, perhaps demonstrating the ongoing influence of traditional narratives of Europe's origins. ${ }^{6}$ In the medieval period, the sense of a civilized Europe remained, but shifted to intrinsically link Latin Christendom with civilization; the bounds of Latin Christendom became the logical conceptual bounds of Europe as well. ${ }^{7}$ By the time printed maps began to appear in the late fifteenth century, there was a well-established tradition of viewing Europe as a conceptual entity with ties to Roman Catholicism and to the glorified Classical era. However, radical changes to geographic knowledge and the religious landscape of sixteenth century Europe forced a recasting of Europe's sociocultural definition and geographical limits.

The sheer breadth of the new territory revealed to European eyes from 1492 onwards forced a reconsideration of Europe's place in the world. The prevailing European conception of the globe in the fifteenth century was of a single world-continent ringed by islands, a misconception famously articulated by Columbus, who "died insisting on [Central America and the Caribbean's] Asian identity." Following the eventual realization that the Americas formed a whole new continental landmass, European conceptions shifted. With the Treaty of Tordesillas (1494), the newly discovered realms of the Atlantic and Indian Oceans were divided on cartographic lines between Portugal and Spain. ${ }^{10}$ In Denis Cosgrove's words, "the Atlantic was now a European geopolitical space, and the pope claimed Christ's delegated authority over it." " Despite a far less concrete European presence around the Indian Ocean, it was similarly placed

\footnotetext{
${ }^{5}$ Edith Hall, Inventing the Barbarian: Greek Self-Definition through Tragedy (Oxford: Clarendon Press, 1989).

${ }^{6}$ Anthony Pagden describes Europe as existing since the $4^{\text {th }}$ century BCE, unified by generally common governmental and political structures, "Introduction" to The Idea of Europe: From Antiquity to the European Union, ed. Pagden (Cambridge: Cambridge University Press, 2002), 3-5; Arnold Toynbee argued that Greek seafarers saw the difference between Europe and Asia within the narrow scope of the Aegean Sea- Lewis \& Wigen and Pocock take his stance, Lewis \& Wigen, The Myth of Continents, 21-3; J. A. Pocock, "Some Europes in Their History" in The Idea of Europe, 56-7; Denis Cosgrove ties his discussion of Western geography to the myth of the rape of Europa, Apollo's Eye: A Cartographic Genealogy of the Earth in the Western Imagination (Baltimore \& London: The Johns Hopkins University Press, 2001), 12-13.

${ }^{7}$ William Chester Jordan, “"Europe' in the Middle Ages" in The Idea of Europe, 74-6.

${ }^{8}$ Allusions to classical texts remained visible in European geography for quite some time, however, as evidenced in Appendix I: Ortelius refers to classical myth with his depiction of Zeus as a bull and Europa within the title image.

${ }^{9}$ Cosgrove, Apollo's Eye, 83. Cosgrove discusses the development of the world-continent theory in Classical thought in "Chapter two: Classical Globe" of Apollo's Eye, 29-53.

${ }^{10}$ Ibid., 83-5; Alison Sandman, "Mirroring the World: Sea Charts, Navigation, and Territorial Claims in Sixteenth-Century Spain" in Merchants and Marvels: Commerce, Science, and Art in Early Modern Europe, eds. Smith \& Findlen (London: Routledge, 2002), 97-101.

${ }^{11}$ Cosgrove, Apollo's Eye, 84.
} 
by the pope under nominal Christian- Portuguese- geopolitical control. Europe's initial response to their discovery of vast new areas of the globe was to assimilate them into their pre-existing system, both by declaring the sovereignty of European kingdoms over them and by, at least at first, refusing to believe that they were something entirely new. ${ }^{12}$

Europe was by 1500 a region self-defined by its shared "civilization," yet the foundations of that civilization were soon to be shaken by the tremors of the Protestant Reformation. The division of Latin Christendom into Lutherans and Catholics shattered the unity of Christendom, before European religious unity was further eroded by the appearance of Calvinists, Anabaptists, Anglicans, and others. ${ }^{13}$ Such divisions forced new criteria for belonging to Europe: neither the Classical Europe in opposition to Asia and Africa, nor the medieval Europe synonymous with a Latin Christian body under the spiritual direction of the papacy. Several streams of thought have developed to explain the reshaped concept of Europe that began to form in the sixteenth century. Perhaps simplest of these remoulded logics of European cohesion was the expansion of European identity to all things Christian, whether Catholic, Protestant or the previously excluded Eastern Orthodox Church. ${ }^{14}$ The growth of humanism in particular affected many aspects of European identity, but its varied regional interpretations lead also to varied scholarly arguments for its impact on how Europe was perceived. In Holland, Europeanness seems to have become associated with Republican freedom, while in the imagination of the Habsburg Emperors, the continent was nearly the opposite: the object of their dominion and domination stretched to its farthest possible geographic limits. ${ }^{15}$ Most of all, Europe came to be seen by the intelligentsia as the region responsible for the liberal values and scientific pursuit of progress of the Scientific Revolution and the Enlightenment. ${ }^{16}$ This secular bent for defining Europe as the home of rationalist, empirical thought was expressed in the other great geographic division of the time, that of West and East, Occident and Orient. ${ }^{17}$ By the sixteenth century, ideas of Europe and its limits had been developing for close to two millennia, yet those ideas experienced critical further development under the influence of secular humanism, the Reformation and the purported discovery of the Americas and other parts of the world by Europeans.

\footnotetext{
12 "America's physical separation from Eurasia was not fully confirmed to Europe until Vitus Bering's second expedition, in 1741." Cosgrove, Apollo's Eye, 83.

${ }^{13}$ The Reformation's final blow to unified Christendom came at the end of a long period of turmoil within Christendom characterized by heresies and the Great Schism of the Papacy, Jordan, "Europe' in the Middle Ages," $88-9$.

${ }^{14}$ This expansion of "Christendom" into something greater than Catholicism was problematic on several levels for geographers: the expansion of the Ottoman empire into formerly Christian lands in Eastern Europe and the presence of long-established Churches outside the European sub-continent (Nestorians, Coptics, etc.) being the most evident.

${ }^{15}$ Hans W. Blom, "The Republican Mirror: The Dutch Idea of Europe" in The Idea of Europe, 91-115; Pocock, "Some Europes in Their History," 57-8.

${ }^{16}$ Pocock, "Some Europes in Their History," 62-7.

${ }^{17}$ Discussed at greater length later in this essay. See Lewis \& Wigen, The Myth of Continents, 47-103.
} 
As much as Europe was a sociocultural entity, it remained one innately geographical, and needed to be placed on the map. Europeans' sudden direct contact with most of the rest of the world made classifying and depicting those new regions in opposition to Europe a great problem. Columbus' certainty that he had found the eastern reaches of Asia was quickly realized as a mistake, leaving the monumental task of inventing a new basic structure for world geography for sixteenth-century European scholars. The academic field that first tackled this project of reinventing the world's geographic structure was cosmography, whose goal was the description of the heavens and the earth, contributing to the earth sciences, geography and astronomy. The centre of the effort to cosmographically describe the New World was in Spain, where cosmographers at the Council of the Indies interpreted a constant incoming flow of eyewitness accounts of new territories to create new cartographic interpretations of American geography. ${ }^{18}$ Establishing a common basis for the differentiation of continents that could still keep the essential distinctions between Europe, Asia and Africa formed another part of this work. ${ }^{19}$ While contending with the challenge of allowing Europe's unique sociocultural identity to be expressed geographically, cosmographers also had to contend with the growing influence of a scientific worldview based on empirical measurement and mathematics. By the end of the sixteenth century, Spanish cosmographers' method of interpreting descriptive accounts was disappearing in favour of new methods based on measurement and calculation of distances and geographical relationships. ${ }^{20}$ Whether through cosmographic interpretation or mathematical description, however, attempts to synthesize the growing corpus of European geographic knowledge about the world were a powerful impetus for the growth of cartography's importance from the fifteenth to eighteenth centuries.

Cartographers' attempts to accurately portray the world's surface could only be expressed by the cartographic production technologies available to them. Fortunately for the early modern mapmaker, map production technology made several major advances in the fifteenth and sixteenth centuries that allowed greater production of essentially identical maps, reflecting the growth of standardization as a European cultural value as well. These advances were spurred on by a general increase in cartographic prestige during the period. Arthur H. Robinson contends that "the first printing [...] in 1472, of a simple, allegorical map was an important event in the

\footnotetext{
${ }^{18}$ María Portuondo's Secret Science: Spanish Cosmography and the New World (Chicago \& London: The University of Chicago Press, 2009) describes this entire process in great detail, as well as the decline of cosmography at the end of the sixteenth century.

${ }^{19}$ Lewis \& Wigen, The Myth of Continents, 25-31.

${ }^{20}$ Portuondo's final chapter describes this practice in detail, "Chapter Seven: Cosmography Dissolves" in Secret Science, 257-98.
} 
history of communication." ${ }^{21}$ Woodcut maps like this first one were common from its creation until the mid-sixteenth century, when they were replaced by more durable and easily modifiable copper plates. Both woodcut and copperplate maps were produced in large batches of identical prints, leading to generally more stable conceptions of the appearance of the world's surface from their standardization and sheer quantity. If a particular map was commercially successful, it would be reproduced in further publications, perhaps with slight modifications to account for new geographic information. ${ }^{22}$ Not only map printing but also other modes of map production flourished. Painted and manuscript maps continued to be produced all through this period, with painted maps holding especial significance for their ubiquity in the homes of the wealthy and powerful. Interest in creating world maps, atlases and other modes of cartographic representation was initiated in part by the discovery of classical texts describing the earth's geography, most notably Ptolemy's Geographia. ${ }^{23}$ Ties to Antiquity were a sure source of prestige, power, and scholarly interest in the humanist era of the fifteenth and sixteenth centuries. Maps were produced in several manners from the fifteenth to the eighteenth centuries, with new technologies allowing more varied geographic interpretations of higher qualities to be produced in greater quantities than ever before. ${ }^{24}$

Early modern mapmakers were working to represent the globe as it stood in nature with the greatest diversity of cartographic tools yet available to Europeans. More maps were being produced in more different manners than ever before, and were also coming to resemble the conventional representations of the globe seen today. During the fifteenth century, a European effort to accurately codify and depict the natural world began. ${ }^{25}$ Images of nature became increasingly detailed and were deemed truthful for that detail, yet fundamentally remained interpretations constructed by their artists. ${ }^{26}$ This movement impacted cartography, as cartographic depictions shifted from the allegorical models of the medieval period, still expressed by the first printed map in 1472, to more detailed ones based on natural observation. But being based on scientific measurement and standardized models did not make maps

\footnotetext{
${ }^{21}$ Robinson, "Mapmaking and map printing," 1.

${ }^{22}$ Far more detailed descriptions of the development of woodcut and copperplate map printing are given by David Woodward and Coolie Verner in Chapters 2-3 of Five centuries of map printing, ed. David Woodward (Chicago: University of Chicago Press, 1975), 25-75.

${ }^{23}$ Peter Barber and Tom Harper, Magnificent Maps: Power, Propaganda and Art (London: The British Library, 2010), 14-15. Ptolemy's work was the basis on which humanist cosmographers based their efforts at systematic description of the world's surface in the sixteenth century, Portuondo, Secret Science, 22-6; Cosgrove, Apollo's Eye, 41-6, 52.

${ }^{24}$ Barber \& Harper, Magnificent Maps, 16.

${ }^{25}$ Pamela H. Smith and Paula Findlen, "Introduction: Commerce and the Representation of Nature in Art and Science" in Merchants and Marvels, 1-25.

${ }^{26}$ Dürer's famous image of a rhinoceros formed European ideas of the animal's appearance, but Dürer based that image off a written description and possibly a rhinoceros hide- the famous artist himself certainly never saw the animal alive, Smith \& Findlen, "Introduction," 1-3.
} 
universally truthful or correct in their representation: scientific methods did not cause maps to lose their power to represent and reinforce European ideologies. In fact, the power of those ideologies as they were depicted in maps only grew stronger with its perceived objectivity. J. B. Harley's warning to map viewers applies to early modern maps as well as those of the present day: "[...] we often tend to work from the premise that mappers engage in an unquestionably 'scientific' or 'objective' form of knowledge creation. [...] It is better for us to begin from the premise that cartography is seldom what cartographers say it is." ${ }^{27}$ In the early modern period's development of scientific and standard methods of map creation lies the origin of the idea that maps are an unbiased representation of the earth's surface. Dense detail and labels became the marks of a well-researched and accurate map: Ortelius' and Valck's focus on Europe is expressed through the extreme detail with which they labelled its cities, towns and regions compared to those outside European space. ${ }^{28}$ Historic maps must be viewed not as increasingly truthful replications of universally apparent geographic knowledge, but rather as interpretations that remain expressions of the power dynamics and regional divisions espoused by their makers. The power latent in the perceived truth of cartographic representations made them more and more appealing to early modern Europeans: maps became powerful tools in political debates over empire and sovereignty.

Maps transform geographic understandings of the lay of the land into seemingly scientific representations of it, but also simplify geographic information to make it easily comprehensible. This combination made maps incredibly powerful when presenting political plans or diplomatic evidence. Chandra Mukerji traces how maps were not only used as practical representations of the land by seventeenth century French engineers, but also as political tools to explain and promote infrastructure projects to the royal authorities. ${ }^{29}$ Jeremy Black argues that maps became ever more common as political tools from the Peace of Westphalia (1648) onward, their power evidenced by the conflict they caused as bordering states disagreed over the exact borders drawn out of formerly undefined frontier regions. ${ }^{30}$ By the late eighteenth century, political leaders were so accustomed to using maps to conceive of their territories that a Habsburg prince demanded maps be made of his Transylvanian frontier province so that he could understand the limits of his

\footnotetext{
27 J. B. Harley, “Deconstructing the Map,” Cartographica 26, no. 2 (1989): 1.

${ }^{28}$ See Appendices I and II. The differences between the two maps also exemplify the superficiality of such improvements: Valck's map has cleaner lines, sharper images, and more vibrant colouring than Ortelius', but the actual information within the labels is essentially the same aside from greater detail in the terrain of the Asian and African interiors.

${ }^{29}$ Chandra Mukerji, "Cartography, Entrepreneurialism, and Power in the Reign of Louis XIV: The Case of the Canal du Midi” in Merchants and Marvels, 248-76.

${ }^{30}$ Jeremy Black, "Change in Ancien Régime International Relations: Diplomacy and Cartography, 1650-1800," Diplomacy and Statecraft 20 (2009): 20-9.
} 
sovereignty there. ${ }^{31}$ Geography in English universities around the turn of the seventeenth century applied increasingly mathematical methods to create charts and maps that expressed growing English imperium and made simpler the trans-Atlantic journey to and from American colonies. ${ }^{32}$ The increasing political power of maps is also shown in the resolution to a Spanish debate between two models of Atlantic sea charts. The charts' initial purpose was as tools to help pilots safely guide merchants between Spain and its American colonies: early charts were practical objects that could guide someone across the Atlantic with only a compass, but lacked a standardized cartographic projection. ${ }^{33}$ Academic Spanish cosmographers balked at the use of these older charts, demanding new ones that used a standard cosmographical projection, yet required much more effort from pilots in the form of frequent calculations of latitudes with navigational tools. ${ }^{34}$ Political exigency made the final decision in favour of the cosmographers, whose charts had both scientific correctness and the advantageous placement of valuable territories under Spanish rule according to the Treaty of Tordesillas working in their favour when presented to imperial authorities. ${ }^{35}$ Evidently, maps were far more than simply tools used to get from place to place. During the fifteenth to eighteenth centuries, maps took on increasing political significance because they could express complicated geopolitical information in a clear, scientific manner.

The issues of empire and power as pertaining to cartography also expressed themselves in a prevailing focus on mapping seas, shorelines and other waterways. ${ }^{36}$ Early modern empires, especially global ones, could hardly claim to have complete control over most of the territory their cartographers claimed for them. Lauren Benton suggests that historians conceptualize imperial sovereignty as a series of corridors and enclaves of legal control within broad swathes of claimed sovereign territory:

Maritime empires represented this pattern most clearly, with their networks of sea lanes connecting dispersed settlements or trading posts. But territorial expansion in Europe also occurred through the creation and protection of corridors and enclaves. [...] Imagining

\footnotetext{
${ }^{31}$ Madalina-Valeria Veres, "Putting Transylvania on the Map: Cartography and Enlightened Absolutism in the Habsburg Monarchy," Austrian History Yearbook 43 (2012): 141-64.

${ }^{32}$ Lesley Cormack, Charting an Empire: Geography at the English Universities, 1580-1620 (Chicago: University of Chicago Press, 1997).

${ }^{33}$ These practical charts were comprised of two overlaid longitudinal and latitudinal grids, meaning that each represented two equators and four poles! Sandman, "Mirroring the World," 91-7.

${ }^{34}$ Ibid., 96-7.

${ }^{35}$ Ibid., 97-101. The Treaty of Tordesillas split the world in two along meridional lines; the latitude of discovered territories determined their ownership by either Spain or Portugal as per papal decree in 1494.

${ }^{36}$ Columbus himself paid close attention to opportunities for maritime expansion and commerce, noting several great natural harbours as selling points for the "Indies' he landed upon, Lauren Benton, A Search for Sovereignty: Law and Geography in European Empires, 1400-1900 (New York: Cambridge University Press, 2010 ), 20.
} 
and enlarging empire sometimes appeared synonymous with efforts to gather information about corridors of control, including mapping and describing ocean passages, river networks, merchant roads, and other travel routes. Enclaves such as missions, trading posts, towns, and garrisons were strung like beads along interconnected corridors. [...] these patterns and practices produced political geographies that were uneven, disaggregated, and oddly shaped- and not at all consistent with the image produced by monochrome shading of imperial maps.

Land routes played a role as corridors in all empires, but waterways were overwhelmingly the main form of transport and communication between European metropoles and their colonies in the early modern period. As such, shorelines were the most accurately described feature of almost any European world map from the period, with negligible attention paid to the uncharted hinterlands not far from European colonies and trading posts. ${ }^{38}$ The maritime orientation of European cartography was a clear and visible expression of European ideologies and imperial interests in maps, belying cartographers' claims to present accurate images of all the Earth's parts. While early modern maps increasingly claimed to be accurate representations of world geography, most often that accuracy was limited in scope to the littoral edges of landmasses.

During the early modern period, the classical and medieval sense of geography that focused on establishing Europe's difference from Asia and Africa grew into a vibrant scholarly field seeking to cartographically describe a huge range of territories previously unknown to Europeans. Cartographers initially relied on cosmographic techniques to portray the world in a systematic fashion. Eventually, however, the use of cosmography declined as the growing scientific ideology of the sixteenth century took hold of mapmakers. Although cartographers applied increasingly mathematical and observation-based techniques to their craft, those maps continued to express European ideology, power and exceptionalism, rather than being the unbiased representations of the Earth's form cartographers claimed them to be. The perceived objectivity and correctness of cartographic representation made them valuable political tools for rulers and diplomats. True objectivity was unnecessary for maps to be truthful in certain regards: Europe was obviously exceptional in all things to early modern Europeans, and world geography should be no exception. The growing European stake in global power reinforced this assumption over time, and exoticism of all things not European played an important role in defining what European meant. This exoticism came to be an unquestioned hallmark of most European maps during the seventeenth century.

\footnotetext{
${ }^{37}$ Benton, $A$ Search for Sovereignty, 2.

${ }^{38}$ Cosgrove, Apollo's Eye, 88. See also both appended maps: both cartographers label settlements and rivers outside European space, but only cities with economic or historic significance are depicted beyond the littoral fringe of the Mediterranean and Black seas. Of note here is the greater detail of African and Asian terrain in Appendix II: either Valck simply knew more than Ortelius, or he saw value in including such detail where Ortelius did not.
} 
Any discussion of exoticism must recognize the importance of the conceptual divide between the "East" or "Orient" and the "West." Edward Said's genre-defining 1979 book, Orientalism, described a particular brand of European exoticism centred on the idea of a rational, scientific, hard-working West in opposition to an emotional, technologically backward and opulent Orient.

${ }^{39}$ Said's theory in all its parts cannot be directly applied before the dominant European empires of the nineteenth century, yet his Orientalism is only the latest in a long series of conceptual divides between East and West by Europeans. ${ }^{40}$ Ideas of East and West in Europe are intrinsically linked to the ideas of Europe and Asia from whence they developed. In the early modern period, conceptions of East and West were augmented by the rise of the Ottoman Empire as a legitimate, perennial threat to Europe on its Eastern border. The savagery of Ottoman warriors and the opulence of their sultan were cast as the cultural opposite of European refinement and rationality. ${ }^{41}$ After much of Eastern Europe was conquered from the Ottomans by Habsburg forces, Ottoman figures continued to be depicted as backwards and barbaric, but lost their savage edge in favour of tropes of wasteful despotic luxury. Conceptual East-West divides have a long history in European thought, but in the early modern period began to express overt exoticism of the Ottomans who exemplified the East to contemporary Europeans. The Ottomans were only an early, particularly prevalent example of a European conceptualization of exoticism that became ubiquitous in the early modern period. Other brands of exoticism of all things considered non-European began to appear.

The idea of Europe, the perceived objectivity of maps, and expressions of European superiority and hegemony came together in the form of cartographic exoticism in the early modern period. Benjamin Schmidt credits the province of Holland with "inventing exoticism" through its role as a cartographic centre, home to "geographers nonpareil of early modern Europe." sixteenth and seventeenth centuries, Amsterdam and its environs came to be the major map-producing centre for all of Europe. Maps made there were distributed across Europe in

\footnotetext{
${ }^{39}$ Edward Said, Orientalism (New York: Vintage Books, 2003 (reprint, original 1978)).

${ }^{40}$ Said himself is careful to acknowledge the periodization of Orientalism's applicability, p22 of Orientalism, but many other scholars have qualified and modified his theory to fit other periods. See Chapters $2 \& 3$ of Lewis \& Wigen, The Myth of Continents, 47-103.

${ }^{41}$ European ideas about the barbarity of the Turks were largely mythologized, sparked by the imminent threat to Christians perceived in the Muslim presence in Eastern Europe. Charlotte Colding Smith has used German pamphlets (Flugblätter) to trace the evolution of the exoticized Turk in the German states, Images of Islam, 1453-1600: Turks in Germany and Central Europe. London: Pickering \& Chatto, 2014; Palmira Brummett describes the development of the barbaric Turk: "Chapter 5 - Heads and Skins: Mapping the Fallen Turk" in Mapping the Ottomans: Sovereignty, Territory, and Identity in the Early Modern Mediterranean (Cambridge: Cambridge University Press, 2015), 187-238.

${ }^{42}$ Benjamin Schmidt, "Inventing Exoticism: The Project of Dutch Geography and the Marketing of the World, circa 1700," in Merchants and Marvels, 350.
} 
original and translated forms, with a demonstrated impact on general European conceptions of geography. ${ }^{43}$ During the late seventeenth and early eighteenth century, these Dutch centres began to present geography in terms of an opposition between a rational, civilized Europe and the exotic marvels of the rest of the world. Objects deemed marvellous enough began to be appropriated into European tropes of exoticism, in essence trivializing the rest of the world into an object of study for European rationalism. Maps and other geographic representations became more and more permeated with various "indicators of exoticism," with semi-nude Indian figures or palm trees among the most common. ${ }^{44}$ Such markers connoting the presence of primitive peoples were not new, as evidenced in the similar use of nomadic tents in eastern Russia by Ortelius in 1570, but were unique for their proliferation and disregard for geographic accuracy in choosing specific exotic markers. ${ }^{45}$ Through the representation of the world as an object under European control, a clearer sense of what was European or Western came into being. Europe was the intellectual and imperial dominator of the earthly sphere, with those inhabiting other regions merely specimens living in abject ignorance of the benefits of European culture. Geography, cartography and exoticism were interwoven concepts in early modern Europe, as the scientific power of European rationality was used to represent the unenlightened peoples it believed itself to have surpassed.

Cartography and geography experienced a boom in the early modern period, leading to the coalescence of a European identity built through exoticism. Europe as a conceptual entity has a long history, harking back to Ancient Greece. The idea of Europe as commonly known today, the birthplace of rationalism, science and ordered thought, began to appear as a result of the need to comprehend vast new geographic areas discovered in the sixteenth century. A growing emphasis on scientific observation and mathematical calculation exerted itself upon the fields of geography and cartography, developing maps into objects of perceived truth. This truth gave maps incredible political and symbolic power as expressions of both European science and empire. Yet despite newly scientific methods of production, maps remained products of the worldviews and perspectives of their makers, and remain so today. As a single Europe began to conceptually solidify in the early modern period, cartographic exoticism helped to firmly establish that identity by placing it in opposition to less appealing exoticized figures. Maps were uniquely positioned to help stabilize the idea of Europe: they could both mark its geographic boundaries and demonstrate its influence over global affairs. Even more poignantly, cartography as practiced in early modern Europe was a quintessentially European field, an objective tool of science that

\footnotetext{
${ }^{43}$ Ibid., 362-4.

${ }^{44}$ Palms in New England, and North American-looking Indians in Brazil show the power of association between certain images and exoticism: Schmidt, Inventing Exoticism: Geography, Globalism and Europe's Early Modern World (Philadelphia: University of Pennsylvania Press, 2015), 250-1.

${ }^{45}$ See Appendix I.
} 
could be used to further imperial and political interests, and had practical value when used to cross the world's still novel oceans. Even as cartography portrayed European power, it itself was the culmination of important trends of early modern European history. 
Appendix I:

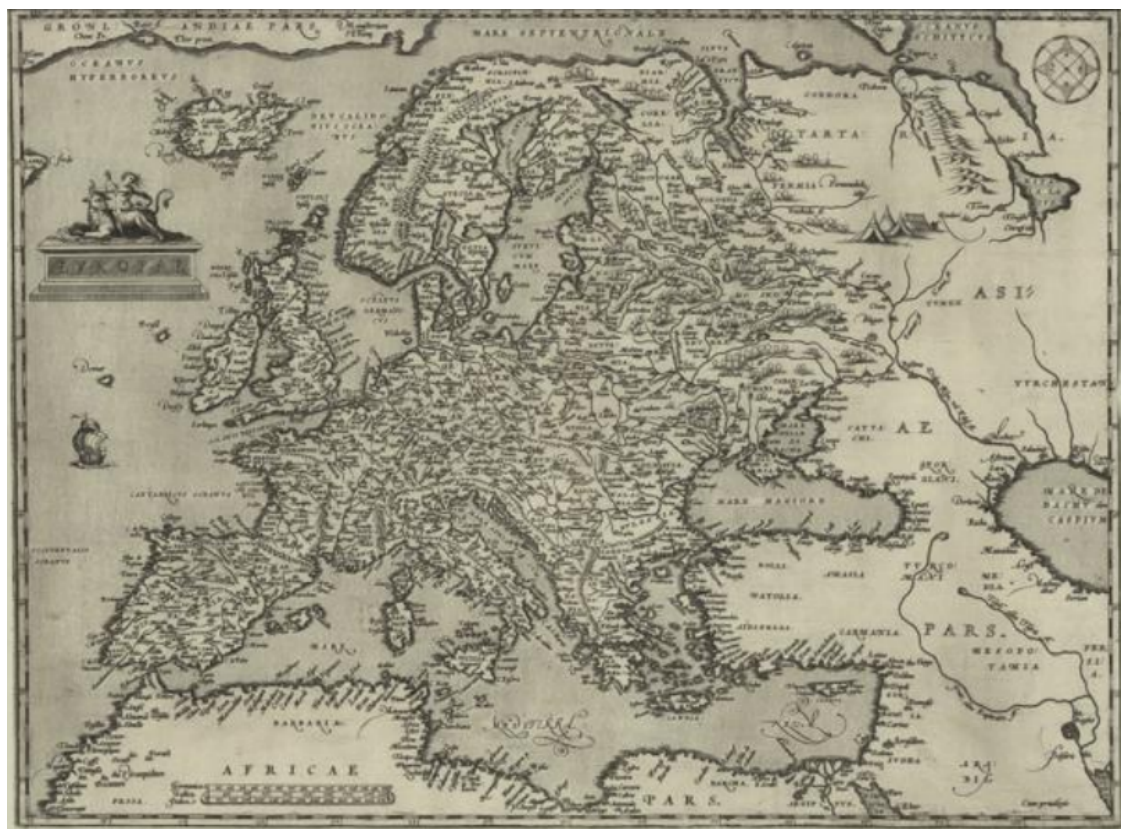

Abraham Ortelius' map of Europe (Antwerp, 1570). This map was included in Ortelius' Theatrum Orbis Terrarum, considered the first modern atlas and a major commercial success: it would have been seen by many people across Europe.

Appendix II:

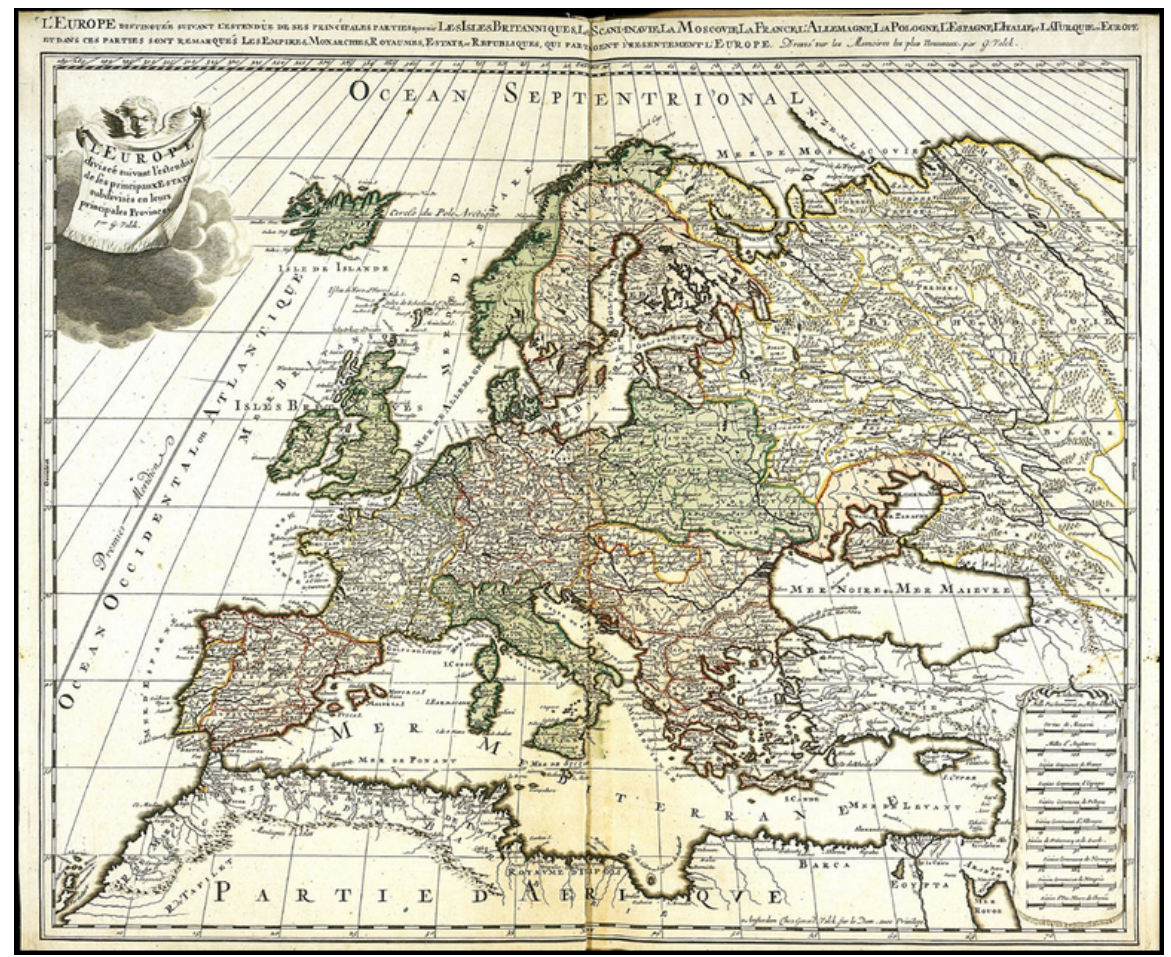

Gerard Valck's ca. 1686 map of Europe reflects improvements in cartography since Ortelius' time, but gives a similar overall impression of Europe. 
Bibliography

Barber, Peter and Tom Harper. Magnificent Maps: Power, Propaganda and Art. London: The British Library, 2010.

Benton, Lauren. A Search for Sovereignty: Law and Geography in European Empires, 1400-1900. New York: Cambridge University Press, 2010.

Black, Jeremy. "Change in Ancien Régime International Relations: Diplomacy and Cartography, 1650-1800.” Diplomacy and Statecraft 20 (2009): 20-9.

Blom, Hans W. "The Republican Mirror: The Dutch Idea of Europe." In The Idea of Europe: From Antiquity to the European Union. Edited by Anthony Pagden. Cambridge:

Cambridge University Press, 2002. 91-115.

Brummett, Palmira. Mapping the Ottomans: Sovereignty, Territory, and Identity in the Early Modern Mediterranean. Cambridge: Cambridge University Press, 2015.

Cormack, Lesley B. Charting an Empire: Geography at the English Universities, 1580-1620. Chicago: University of Chicago Press, 1997.

Cosgrove, Denis. Apollo's Eye: A Cartographic Genealogy of the Earth in the Western Imagination. Baltimore and London: The Johns Hopkins University Press, 2001.

Hall, Edith. Inventing the Barbarian: Greek Self-Definition through Tragedy. Oxford: Clarendon Press, 1989.

Harley, J. B. "Deconstructing the Map." Cartographica 26, no. 2 (1989): 1-20.

Jordan, William Chester. "Europe' in the Middle Ages." In The Idea of Europe: From Antiquity to the European Union. Edited by Anthony Pagden. Cambridge: Cambridge University Press, 2002. 72-90.

Lestringant, Frank. Mapping the Renaissance World: The Geographical Imagination in the Age of Discovery. Translated (from French) by David Fausett. Cambridge: Polity Press, 1994.

Lewis, Martin W. and Kären E. Wigen. The Myth of Continents: A Critique of Metageography. Berkeley: University of California Press, 1997.

Mukerji, Chandra. "Cartography, Entrepreneurialism, and Power in the Reign of Louis XIV: The Case of the Canal du Midi." In Merchants and Marvels: Commerce, Science, and Art in Early Modern Europe. Edited by Pamela H. Smith and Paula Findlen. London: Routledge, 2002. 248-76.

Pagden, Anthony. "Europe: Conceptualizing a Continent." In The Idea of Europe: From Antiquity to the European Union. Edited by Anthony Pagden. Cambridge: Cambridge University Press, 2002. 33-54.

--."Introduction" to The Idea of Europe: From Antiquity to the European Union. Edited by Anthony Pagden. Cambridge: Cambridge University Press, 2002. 1-32.

Pocock, J. G. A. "Some Europes in Their History." In The Idea of Europe: From Antiquity to the European Union. Edited by Anthony Pagden. Cambridge: Cambridge University Press, 2002. 55-90.

Portuondo, María M. Secret Science: Spanish Cosmography and the New World. Chicago \& London: The University of Chicago Press, 2009. 
Robinson, Arthur H. "Mapmaking and map printing: The evolution of a working relationship." In Five centuries of map printing. Edited by David Woodward. Chicago: University of Chicago Press, 1975. 1-23.

Said, Edward. Orientalism. New York: Vintage Books, 2003 (reprint, original 1978).

Sandman, Alison. "Mirroring the World: Sea Charts, Navigation, and Territorial Claims in Sixteenth-Century Spain.” In Merchants and Marvels: Commerce, Science, and Art in Early Modern Europe. Edited by Pamela H. Smith and Paula Findlen. London: Routledge, 2002. 83-108.

Schmidt, Benjamin. Inventing Exoticism: Geography, Globalism, and Europe's Early Modern World. Philadelphia: University of Pennsylvania Press, 2015.

--."Inventing Exoticism: The Project of Dutch Geography and the Marketing of the World, circa 1700." In Merchants and Marvels: Commerce, Science, and Art in Early Modern Europe. Edited by Pamela H. Smith and Paula Findlen. London: Routledge, 2002. 347-369.

Smith, Charlotte Colding. Images of Islam, 1453-1600: Turks in Germany and Central Europe. London: Pickering \& Chatto, 2014.

Smith, Pamela H. and Paula Findlen. "Introduction: Commerce and the Representation of Nature in Art and Science." In Merchants and Marvels: Commerce, Science, and Art in Early Modern Europe. Edited by Pamela H. Smith and Paula Findlen. London: Routledge, 2002. 1-25.

Veres, Madalina-Valeria. "Putting Transylvania on the Map: Cartography and Enlightened Absolutism in the Habsburg Monarchy." Austrian History Yearbook 43 (2012): 141-64.

Woodward, David (ed.). Five centuries of map printing. Chicago: University of Chicago Press, 1975.

\section{Appendix Bibliography}

Appendix I- Abraham Ortelius. Europae. Antwerp: s.n., 1570. Universitätsbibliothek Basel Database. http://dx.doi.org/10.3931/e-rara-12850. Copperplate print. Accessed March 18, 2016.

Appendix II- Gerard Valck. L'Europe divisée suivant l'estendüe de ses principaux estats subdivisés en leurs principales provinces par G: Valck. Amsterdam: Gerard Valck, post-1686. Universitätsbibliothek Bern Database. System number: 001009408. Copperplate print. Accessed March 18, 2016. 